\title{
Clinical aspects and dynamics of auricular parasitosis in Gir cattle ${ }^{1}$
}

\author{
Patrícia V.B. Leite ${ }^{2 *}$, Luiza B. Leite ${ }^{2}$, Arildo P. da Cunha², Marcos X. Silva ${ }^{2}$, Ana \\ Cristina P.P. Bello ${ }^{2}$, Luísa N. Domingues ${ }^{2}$, Antônio Leite $\mathrm{Jr}^{3}$ and Romário C. Leite ${ }^{2}$
}

\begin{abstract}
Leite P.V.B., Leite L.B., Cunha A.P., Silva M.X., Bello A.C.P.P., Domingues L.N., Leite Jr A. \& Leite R.C. 2013. Clinical aspects and dynamics of auricular parasitosis in Gir cattle. Pesquisa Veterinária Brasileira 33(3):319-325. Laboratório de Doenças Parasitárias, Departamento de Medicina Veterinária Preventiva, Escola de Veterinária, Universidade Federal de Minas Gerais, Av. Antônio Carlos 6627, Belo Horizonte, MG 30.123-970, Brazil. E-mail: patriciabossileite@gmail.com

We evaluated the dynamics of ear infestations caused by Rhabditis spp. and Raillietia spp., which were correlated with animal age, intensity of clinical signs and climate factors. Sixty-four Gir cattle were distributed into three groups: GA - 23 calves with 4 to 6 months of age; GB - 18 calves with 7 to 12 months of age; and GC - 23 heifers with 13 to 33 months of age. Five samplings, defined as S1, S2, S3, S4 and S5 were performed every three months from August 2008 to August 2009. The ear secretion was collected using the auricular washing method for the right ear and a swab for the left ear. A clinical assessment of the animals was performed, and they were classified according to the presence and severity of otitis. The highest relative frequency of rhabditosis was $52.2 \%$ in GC at the last sampling. In the first sampling, $42.2 \%$ of the animals were infested by Raillietia spp. The older cattle were more susceptible to infestations by both parasites. No correlation of Rhabditis spp. and Raillietia spp. parasitism with climate factors was found. The results showed that both parasites could infest Gir cattle, and in most cases, there was no co-infestation. Only older animals parasitized by the nematode showed clinical signs of the disease.
\end{abstract}

INDEX TERMS: Cattle, parasitic otitis, Rhabditis spp., Raillietia spp.

RESUMO.- [Aspectos clínicos e dinâmica de parasitoses auriculares em bovinos da raça Gir.] Avaliou-se a dinâmica da infestação auricular causada por Rhabditis spp. e por Raillietia spp., relacionando-a com a idade dos animais, com a intensidade dos sinais clínicos e com os fatores climáticos. Utilizaram-se 64 bovinos Gir, distribuídos em três grupos: GA - 23 bezerros de quatro a seis meses de idade, GB - 18 bezerros de sete a 12 meses e GC - 23 novilhas de 13 a 33 meses. Foram feitas cinco coletas a cada três meses. A secreção auricular foi coletada utilizando o método de lavagem auricular na orelha direita e um swab na orelha esquerda. Fez-se avaliação clínica dos animais classificando-os de acordo com a presença e gravidade da otite. A

\footnotetext{
${ }^{1}$ Received on December 15, 2012.

Accepted for publication on January 28, 2013.

${ }^{2}$ Laboratório de Doenças Parasitárias, Departamento de Medicina Veterinária Preventiva, Escola de Veterinária, Universidade Federal de Minas Gerais (UFMG), Av. Antônio Carlos 6627, Belo Horizonte, MG 30123-970, Brazil. *Corresponding author: patriciabossileite@gmail.com

${ }^{3}$ Veterinário Autônomo, Rua Desembargador Eustáquio Peixoto 228/202, Teófilo Otoni, MG 39803-007, Brazil.
}

maior frequência relativa da rhabditiose encontrada foi de $52,2 \%$, no GC na ultima coleta. Na primeira coleta, $42,2 \%$ dos animais estavam infestados pela Raillietia spp. Os bovinos mais velhos foram mais suscetíveis às infestações de ambos os parasitos. Não foi encontrada correlação entre o parasitismo por Rhabditis spp. e por Raillietia spp. e os fatores climáticos. Concluiu-se que ambos os parasitas podem infestar bovinos da raça Gir e na maioria dos casos, não ocorreram infestações simultâneas. Apenas os animais mais velhos, parasitados pelo nematóide, apresentaram sinais clínicos da doença.

TERMOS DE INDEXAÇÃO: Bovinos, otite parasitária, Rhabditis spp., Raillietia spp.

\section{INTRODUCTION}

Otological cattle diseases are generally neglected in routine clinical examinations; however, studies have shown that otitis in this species is a significant health problem, especially when caused by mites of the genus Raillietia or by free-living rhabdiform nematodes (Duarte \& Hamdan 2004). These parasites are considered the precursors of ex- 
ternal otitis in cattle due to intense irritation and lesions in the external auditory canal (EAC) and the tympanic membrane (Leite et al. 1993).

The otitis caused by nematodes of the genus Rhabditis (Rhabditidae) usually affects both ears and causes an abundant purulent discharge with a large amount of parasites. This disease causes great discomfort and often progresses to otitis media and internal otitis. Damage to the local nerves and abscess formation may occur in the central nervous system (CNS), permanently impairing the animal's performance or even leading to death (Msolla et al. 1993). The first report from Brazil was published in the early 1970s and described the species Rhabditis (Rhabditis) freitasi and Rhabditis (Rhabditis) costae (Martins Jr et al. 1974). The disease mainly affects long and cannulated ear cattle, such as the Gir breed (Bos taurus indicus), and is present in the herds of several Brazilian states (Leite et al. 1993, Vieira et al. 1998, Duarte \& Hamdan 2004, Abdalla et al. 2008), with infestations rates varying from 78.4 to $100 \%$.

The parasitosis caused by the mite Railiettia spp. is globally distributed and affects buffaloes, sheep, goats and cattle of all breeds in Brazil (Nunes \& Nunes 1975), with infestaton rates reaching up to $100 \%$ (Faccini et al. 1992). Although some studies suggest that Raillietia spp. are irrelevant for Gir animals, a prevalence of $42 \%$ has already been reported (Leite et al. 1989). Similar to nematodes, this parasite is responsible for otitis of varying intensity, but asymptomatic infestation is the most common finding.

The diagnosis of parasitic otitis is performed in severe cases by a simple observation of the EAC and is indicated by secretion of yellowish color and an unpleasant odor. Confirmation of the etiological agent is performed through collecting material by swab or washing the auditory canal with water or $3 \%$ boric ethanol (Leite et al. 1989, Facuri Filho et al. 1990, Duarte \& Handam 2004).

The Gir breed, which is mostly affected by the nematodiosis, is noted for its milk production capacity at reduced costs (Ledic 2009). The current demand on the Brazilian market for the genetic stock of this breed is increasing (Rentero 2008), and this high demand justifies the need for studies regarding parasitic otitis, which is considered a limiting factor for raising of these animals.

This study proposes to extend the knowledge of the dynamics and clinical aspects of ear parasites in cattle to provide the establishment of preventive protocols and therapeutic interventions.

\section{MATERIALS AND METHODS}

The study was conducted on a farm located in the State of Minas Gerais, Brazil ( $17^{\circ} 51^{\prime} 15^{\prime \prime}$ S $\left.41^{\circ} 30^{\prime} 23^{\prime \prime} W\right)$. Sixty-four Gir cattle were used (males and females), which were maintained on pastures and divided into the following groups: group GA with 23 animals of 4 to 6 months of age, group GB with 18 animals of 7 to 12 months of age, and group GC with 23 animals of 13 to 33 months of age. Five samplings, defined as S1, S2, S3, S4 and S5 were performed from August 2008 to August 2009, every three months, for the diagnostics for Rhabditis spp. and Raillietia spp. infestation.

The animals were restrained in a specific and appropriate place, with the body and neck immobilized. The head was immobilized manually (Fig.1A) or with the aid of a rope that was passed
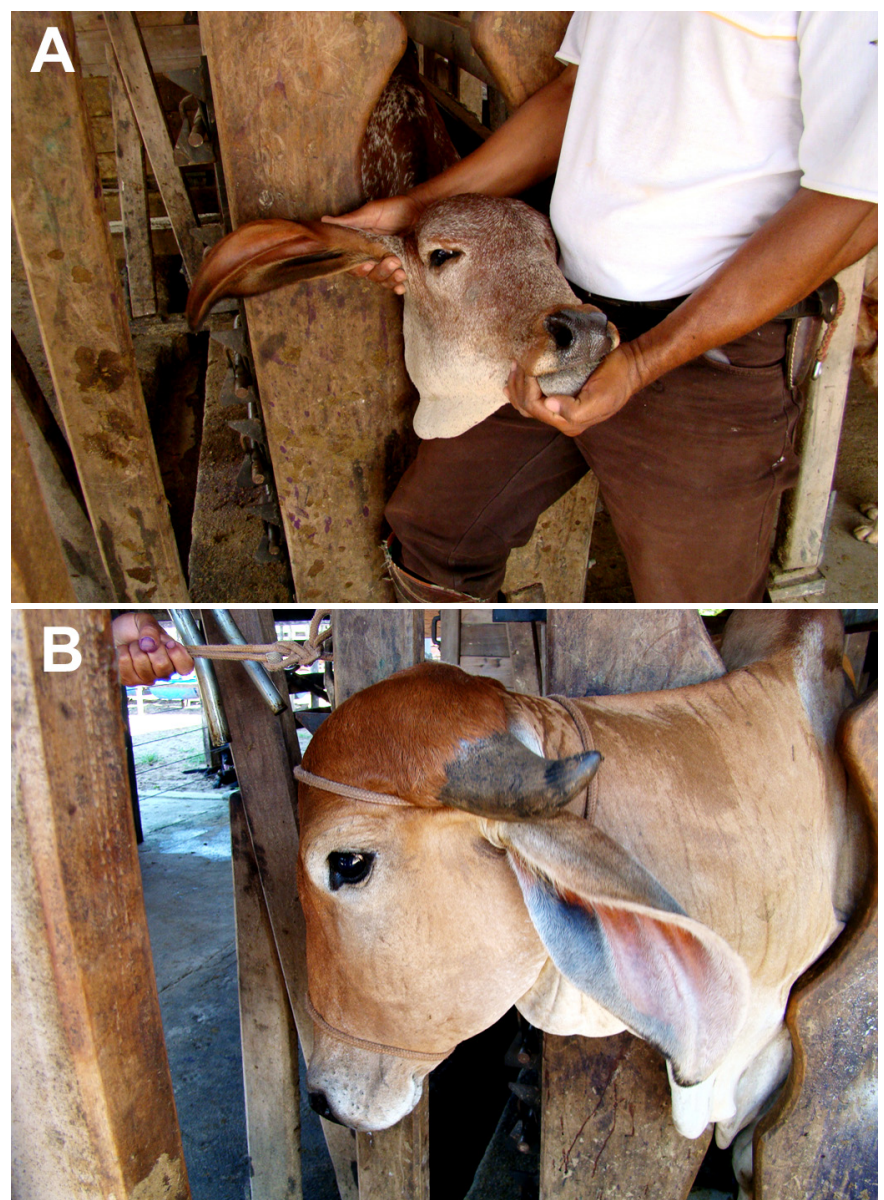

Fig.1. Animal's contention for sampling collect. (A) Calf, (B) heifer

Table 1. Bovine parasitic otitis classification according to clinical signs and presence of parasite

Otitis Symptoms description

(0) Negative Ear and external auditory canal (EAC) with intact skin, clear aspect and a lack of secretion. Cerumen in small quantities with a yellowish or brown color and dry aspect.

(1) Subclinical Normal general aspect. Absence of visible alterations in the EAC. Increase in the quantity of darkly colored cerumen with moist aspect. Presence of parasites only detectable by parasitological diagnosis.

(2) Mild Normal general aspect. Small quantity of yellowish fluid secretion and a presence of parasites in the early horizontal portion of the EAC. Ear with no visible alterations.

(3) Moderate Normal general aspect but with some degree of distress. Tearing. Yellowish fluid secretion quite evident upon inspection of the ear. Erythematous skin of the EAC with small ulcerated areas. Cervical lymph nodes slightly enlarged.

(4) Severe Apathy and/or distress with repeated head movements. Increase of lymph nodes and edema at the base of the ear. Auditory canal stenosis with ulcerated areas. Large amounts of purulent and/or bloody secretion with a strong odor and a presence of parasites. In some cases, the head and ear may be tilted to the affected side.

(5) Very severe Loss of appetite and dehydration. Head tilted or extended. Sensitivity at the base of the ear. Large amount purulent ear secretion with an unpleasant odor. Purulent nasal and ocular discharge. Facial nerve paralysis with ear and eyelid ptosis. A possible accumulation of food in the side of the mouth. Nystagmus, loss of motor coordination, circling and spasms. 
under the horns and ears so that they were free, what allowed safe access to the EAC (Fig.1B).

The animals were assessed based on the general appearance, the presence of clinical signs, the appearance and intensity of ear lesions, the presence of parasites and nervous impairment. The animals were classified into five categories according to the parameters shown in Table 1.

Two methods were used to diagnose the presence of parasites in each animal. In the right ear, EAC was washed under pressure with filtered water (Leite et al. 1989). An automatic syringe (for anti parasitic application in pour-on formulation - 30ml) was used, attached to a disposable micropipette tip. A total of $60 \mathrm{ml}$ water was injected by two flushes, and the resulting reflux material was collected into a plastic conical tube using a funnel with a large opening (Fig.2A). The tubes were identified by the number of each animal, kept at room temperature and processed on the same day.

The swab was introduced into the left ear, according to the method described by Leite et al. (1994) for a qualitative diagnosis of infestation (Fig.2B). The swab was placed in a glass tube with lid, identified and exposed to the sun for nematode visualization by naked eye.

In the laboratory, the liquid resulting from the washing, which was poured into a Petri dish $(90 \times 15)$, and the swabs were observed on a stereomicroscope (Metrimpex PZO-Labimex., 6.3 and 10x) to check for the presence of parasites. The load of parasitic mites was recorded, and individuals with at least one parasite were considered positive. Moreover, the cattle infested by nema-
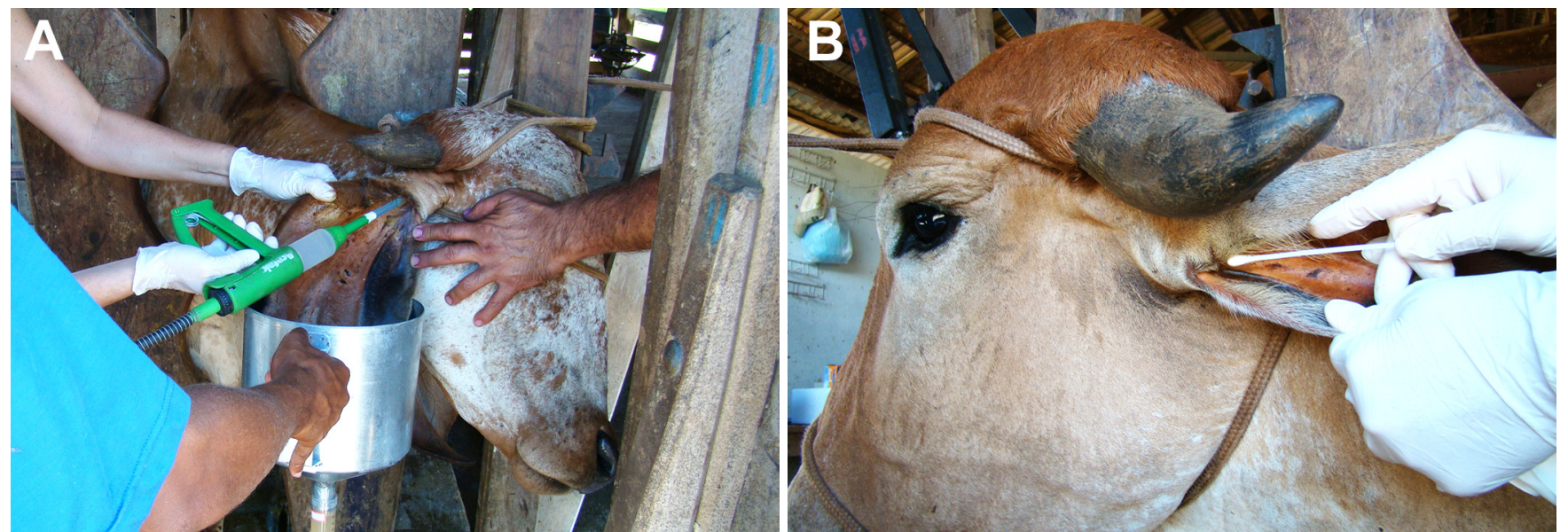

Fig.2. The methods used to diagnose the parasites. (A) External auditory conduct washing, (B) use of swab.

\begin{tabular}{|c|c|c|c|c|c|c|c|c|c|c|c|c|c|}
\hline \multirow{2}{*}{$\begin{array}{c}\text { Sample } \\
\text { (Date) }\end{array}$} & \multirow[t]{2}{*}{ Group } & \multirow{2}{*}{$\begin{array}{c}\text { Number of } \\
\text { animals }\end{array}$} & \multirow[t]{2}{*}{ Positive* } & \multirow[t]{2}{*}{$(\%)$} & \multicolumn{3}{|c|}{ Positive } & \multicolumn{6}{|c|}{ Otitis classification $* *$} \\
\hline & & & & & Bilateral & $\mathrm{RE}$ & $\mathrm{LE}$ & 0 & 1 & 2 & 3 & 4 & 5 \\
\hline S1 & GA & 23 & $0^{\mathrm{a}}$ & - & 0 & 0 & 0 & 23 & 0 & 0 & 0 & 0 & 0 \\
\hline \multirow[t]{3}{*}{ (Aug 08) } & GB & 18 & $0^{\mathrm{a}}$ & - & 0 & 0 & 0 & 18 & 0 & 0 & 0 & 0 & 0 \\
\hline & GC & 23 & $7^{\mathrm{b}}$ & 30.4 & 4 & 3 & 0 & 16 & 2 & 2 & 3 & 0 & 0 \\
\hline & Total & 64 & $7^{\mathrm{A}}$ & 10.9 & 4 & 3 & $\mathbf{0}$ & 57 & 2 & 2 & 3 & $\mathbf{0}$ & $\mathbf{0}$ \\
\hline S2 & GA & 23 & $0^{\mathrm{a}}$ & - & 0 & 0 & 0 & 23 & 0 & 0 & 0 & 0 & 0 \\
\hline \multirow[t]{3}{*}{ (Nov 08) } & GB & 18 & $0^{\mathrm{a}}$ & - & 0 & 0 & 0 & 18 & 0 & 0 & 0 & 0 & 0 \\
\hline & GC & 23 & $6^{\mathrm{b}}$ & 26,1 & 3 & 1 & 2 & 17 & 2 & 2 & 2 & 0 & 0 \\
\hline & Total & 64 & $6^{A}$ & 9.4 & 3 & 1 & 2 & 58 & 2 & 2 & 2 & 0 & o \\
\hline S3 & GA & 23 & $0^{\mathrm{a}}$ & - & 0 & 0 & 0 & 23 & 0 & 0 & 0 & 0 & 0 \\
\hline \multirow{3}{*}{ (Feb 09) } & GB & 18 & $0^{\mathrm{a}}$ & - & 0 & 0 & 0 & 18 & 0 & 0 & 0 & 0 & 0 \\
\hline & GC & 23 & $6^{\mathrm{b}}$ & 26,1 & 5 & 0 & 1 & 17 & 1 & 2 & 3 & 0 & 0 \\
\hline & Total & 64 & $6^{A}$ & 9.4 & 5 & 0 & 1 & 58 & 1 & 2 & 3 & $\mathbf{0}$ & $\mathbf{0}$ \\
\hline S4 & GA & 23 & $0^{\mathrm{a}}$ & - & 0 & 0 & 0 & 23 & 0 & 0 & 0 & 0 & 0 \\
\hline \multirow[t]{3}{*}{ (Mai 09) } & GB & 18 & $0^{\mathrm{a}}$ & - & 0 & 0 & 0 & 18 & 0 & 0 & 0 & 0 & 0 \\
\hline & GC & 23 & $12^{\mathrm{b}}$ & 52.2 & 6 & 3 & 3 & 11 & 2 & 3 & 7 & 0 & 0 \\
\hline & Total & 64 & $12^{A, B}$ & 18.8 & 6 & 3 & 3 & 52 & 2 & 3 & 7 & 0 & o \\
\hline S5 & GA & 23 & $3^{\mathrm{a}}$ & 13.0 & 0 & 3 & 0 & 20 & 3 & 0 & 0 & 0 & 0 \\
\hline \multirow{3}{*}{ (Aug 09) } & GB & 18 & $4^{\mathrm{a}, \mathrm{b}}$ & 22.2 & 0 & 4 & 0 & 14 & 4 & 0 & 0 & 0 & 0 \\
\hline & GC & 23 & $12^{\mathrm{b}}$ & 52.2 & 8 & 4 & 0 & 11 & 2 & 3 & 7 & 0 & 0 \\
\hline & otal & 64 & $19^{B}$ & 29.7 & 8 & 11 & 0 & 45 & 9 & 3 & 7 & 0 & 0 \\
\hline
\end{tabular}

$\overline{\mathrm{GA}}=$ calves 4 to 6 months of age, $\mathrm{GB}=$ calves 7 to 12 months of age, $\mathrm{GC}=$ heifers 13 to 33 months of age.

S1 = sample $1, \mathrm{~S} 2=$ sample $2, \mathrm{~S} 3=$ sample $3, \mathrm{~S} 4=$ sample $4, \mathrm{~S} 5=$ sample 5.

** Total number of animals infested by Rhabditis spp. RE $=$ right ear, LE $=$ Left ear.

*** Classification of otitis level: $0=$ negative, $1=$ subclinical, $2=$ mild, $3=$ moderate, $4=$ severe, 5 = very severe.

Values followed by different common letters in the column within samplings and capital let-

ters among samplings differ by Fisher Exact Test $(\mathrm{P}<0.05)$. 
Table 3. Frequency of cattle infested by Railiettia spp. and number of mites obtained per group in each sampling

\begin{tabular}{|c|c|c|c|c|c|c|c|c|}
\hline \multirow[t]{2}{*}{$\begin{array}{c}\text { Sample } \\
\text { (Date) }\end{array}$} & \multirow[t]{2}{*}{ Group } & \multirow[t]{2}{*}{$\begin{array}{c}\text { Number of } \\
\text { animals }\end{array}$} & \multirow[t]{2}{*}{ Positive* } & \multirow[t]{2}{*}{$\%$} & \multicolumn{2}{|c|}{ Sample results } & \multicolumn{2}{|c|}{$\begin{array}{l}\text { Total number of } \\
\text { collected mites }\end{array}$} \\
\hline & & & & & & & Washed $^{* *}$ & Swab*** \\
\hline S1 & GA & 23 & $11^{\mathrm{a}}$ & 47.8 & 11 & 0 & $21(1.9)^{x}$ & 0 \\
\hline \multirow[t]{3}{*}{ (Aug 08) } & GB & 18 & $6^{a}$ & 33.3 & 6 & 0 & $8(1.3)^{x y}$ & 0 \\
\hline & GC & 23 & $10^{\mathrm{a}}$ & 43.5 & 10 & 1 & $52(5.2)^{y}$ & $1(1.0)$ \\
\hline & Total & 64 & $27^{\text {B }}$ & 42.2 & 27 & 1 & $81(3.0)^{Y}$ & 3 \\
\hline S2 & GA & 23 & $1^{\mathrm{a}}$ & 4.3 & 1 & 0 & $1(1.0)^{x}$ & 1 \\
\hline \multirow[t]{3}{*}{ (Nov 08) } & GB & 18 & $1^{\mathrm{a}}$ & 5.6 & 1 & 1 & $3(1.5)^{x y}$ & 1.5 \\
\hline & $\mathrm{GC}$ & 23 & $7^{\mathrm{b}}$ & 30.4 & 7 & 0 & $10(1.4)^{y}$ & 1.4 \\
\hline & Total & 64 & $9^{A}$ & 14.1 & 9 & 1 & $14(1.4)^{x}$ & 1.4 \\
\hline S3 & GA & 23 & $0^{\mathrm{a}}$ & 0 & 0 & 0 & $0^{x}$ & 0 \\
\hline \multirow[t]{3}{*}{ (Feb 09) } & GB & 18 & $0^{\mathrm{a}}$ & 0 & 0 & 1 & $1(1.0)^{x}$ & 1 \\
\hline & $\mathrm{GC}$ & 23 & $13^{b}$ & 56,5 & 13 & 0 & $35(2.7)^{y}$ & 2.7 \\
\hline & Total & 64 & $13^{A}$ & 20.3 & 13 & 1 & $36(2.5)^{x}$ & 2.5 \\
\hline S4 & GA & 23 & $0^{\mathrm{a}}$ & 0 & 0 & 1 & $0^{x}$ & 0 \\
\hline \multirow[t]{3}{*}{ (Mai 09) } & GB & 18 & $1^{\mathrm{a}}$ & 5.6 & 1 & 0 & $1(1.0)^{x}$ & 1 \\
\hline & GC & 23 & $9^{b}$ & 39.1 & 9 & 0 & $23(2.6)^{y}$ & 2.6 \\
\hline & Total & 64 & $10^{A}$ & 15.6 & 10 & 1 & $24(2.4)^{x}$ & 2.4 \\
\hline S5 & GA & 23 & $1^{\mathrm{a}}$ & 4.3 & 1 & 0 & $1(1.0)^{x}$ & 1 \\
\hline \multirow[t]{3}{*}{ (Aug 09) } & GB & 18 & $0^{\mathrm{a}}$ & 0 & 0 & 0 & $0^{x}$ & 0 \\
\hline & GC & 23 & $4^{b}$ & 17.4 & 4 & 1 & $7(1.8)^{x}$ & 1.8 \\
\hline & Total & 64 & $5^{A}$ & 7.8 & 5 & 1 & $8(1.6)^{x}$ & 1.6 \\
\hline
\end{tabular}

$\overline{\mathrm{GA}}=$ calves 4 to 6 months of age, $\mathrm{GB}=$ calves 7 to 12 months of age, $\mathrm{GC}=$ heifers 13 to 33 months of age.

S1 = sample $1, \mathrm{~S} 2$ = sample 2 , S3 = sample 3 , S4 = sample 4, S5 = sample 5 .

* Total number of animals infested only in the RE, ** Total and average number of mites collected in the RE.

*** Total and average number of mites collected in the LE; RE = right ear, LE = Left ear.

Values followed by different common letters in the column within samplings and capital letters among samplings differ at a $5 \%$ level of significance $(\mathrm{P}<0.05)$.

todes were classified only as positive or negative due the countless parasites found in the animals.

The climate parameters of temperature, relative humidity and precipitation were measured using a thermo-hygrometer (model 5195.03.0.00, INCOTERM) and acrylic pluviometer (Acrylic pluviometer $130 \mathrm{~mm}$ ). Both devices were kept near the pasture where the animals were maintained, throughout the experiment, and the same person collected the data daily between noon and two hours p.m.

The statistical program BIOESTAT 3.0 (Ayres et al. 2003) was used for the frequency distribution analysis (Fisher's exact test) to determine whether there were significant differences in the number of animals infested by the two parasites between the five samplings and also between groups. Differences were considered significant at $\mathrm{p}<0.05$. The non-parametric Kruskal-Wallis test was used to analyze the counts of mites collected in different groups and samplings. The frequencies of both parasites found in the five samples and in the three groups were correlated by a Pearson's test to evaluate the influence of the animal's age on infestations in accordance with Sampaio (2007). The climate factors of relative humidity, temperature and precipitation were correlated with the intensity of otitis caused by the nematode and with the rate of mite infestation using the statistical program SAS (1999) by using PROC CORR Spearman option (SAS 1999).

\section{RESULTS}

Table 2 shows the data regarding the Rhabditis spp. infestations. The findings of both ears were considered; therefore, the number of positive animals per sample and per group is the somatory of the animals in which the nematode was found in the right ear, in the left ear, or in both. The rate of infestation ranged from 9.4 to $10.9 \%$ in samplings S1, S2 and S3, without significant difference among them. However, in samplings S4 and S5, the differences either relative to the other samplings or between each other were significant $(\mathrm{P}<0.05)$, with values of 18.8 and $29.7 \%$ positive animals respectively. The GC had the greatest percentage of positive animals, i.e., $52.2 \%$ in samplings S4 and S5.

In samplings S1, S2, S3 and S4, the nematodes were not found in GA or GB. By contrast, GC had infested animals in all samplings.

Regarding the infestations by the mite Raillietia spp., both results of parasite frequency and the parasitic load, which were obtained in the left ear by a swab, were considered inconsistent for analysis. Therefore, only the results of the right ear, which was washed, were analyzed (Table 3). In a total of 64 animals from all three groups, 27 (42.2\%) were infested by mites in S1, yielding 1 to 13 mites per animal. In the subsequent samplings, the number of positive animals varied, as follows: $14.1 \%$ in S2, 20.3\% in S3, 15.6\% in S4 and $7.8 \%$ in S5, with no significant difference among the results $(\mathrm{P}>0.05)$. Regarding the total number of mites collected, 81 parasites were found in S1, with an average of 3 mites per animal. In the subsequent four samplings, statistically similar $(\mathrm{P}>0.05)$ quantities were collected that were smaller than the total obtained by the first sampling. The animals in GA and GB had lower parasitic loads than those of GC in all samples except for the last, in which statistically similar quantities were found in all groups. The final sampling yielded the fewest mites collected throughout the study. 


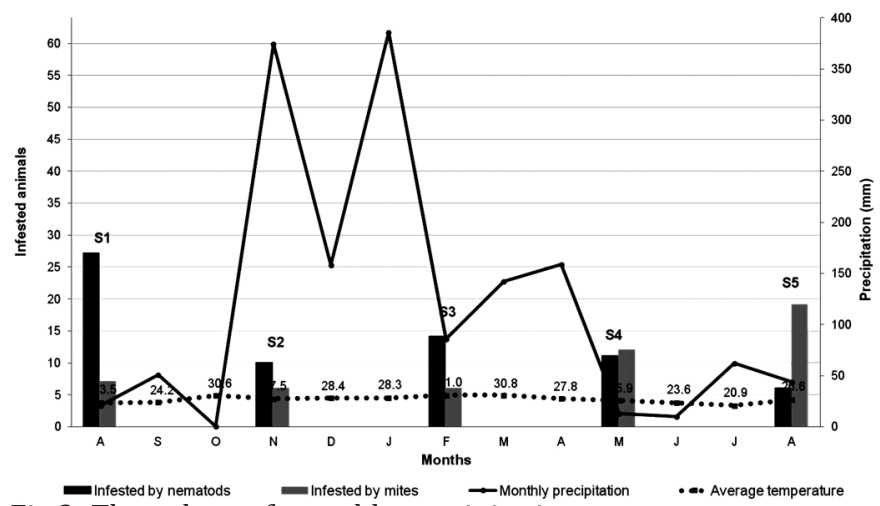

Fig.3. The values of monthly precipitation, average temperature and number of animals positive for Rhabditis spp. and Raillietia spp.

The rate of parasitism caused by the two parasites showed positive correlation with the animal's age $(r=0.44$; $\mathrm{P}<0.05)$. Older animals had more parasites.

Mixed infestations by Rhabditis spp. and Raillietia spp. were found in up to four individuals $(6.3 \%)$ from each sampling. The diagnosis of this association was only possible through the ear washing and was not detected by the swab method.

The clinical signs of otitis were only observed in the subjects infested by nematodes or simultaneously by mites and nematodes. The animals diagnosed only with mites appeared asymptomatic. The maximum intensity of otitis found was grade 3 (moderate), and this level was only observed in individuals from GC over the age of 24 months (Table 1). The statistical analysis confirmed a positive correlation $(\mathrm{r}=0.41 ; \mathrm{P}<0.05)$ between the intensity of the clinical signs of otitis and the animal's age.

Figure 3 shows the values for monthly precipitation and average temperature during the experiment. and the number of animals that were positive for both nematodes and mites in all five samplings. The average monthly temperatures ranged from $23.5^{\circ} \mathrm{C}$ in the winter to $31.0^{\circ} \mathrm{C}$ in summer, and the average temperature for the entire period was $26.9^{\circ} \mathrm{C}$, which was $2.6^{\circ} \mathrm{C}$ above the $24.3^{\circ} \mathrm{C}$ mean temperature recorded previously for the region (IESFATO 2009). The periods of drought and rainfall were well defined, and the annual total precipitation was $1,507.0 \mathrm{~mm}$, which was less than the 1,842.0 $\mathrm{m}$ recorded previously for the region (IESFATO 2009). The relative humidity (RH) remained above $73 \%$, even in the winter months, which was similar to the historical average of $74.8 \%$ for the region. The exceptions were the months of August, September and October of 2008, which had relative humidity of 64,67 and $53 \%$ respectively.

\section{DISCUSSION}

The maximum frequency of cattle infested by Rhabditis spp. was $52.2 \%$ in GC in the fourth and fifth sampling, which is a lower value than those of 78.4 and $94 \%$ found by Vieira (1998) and Duarte et al. (2001). These differences may be attributed either the diversity of herd management or age of the animals studied.

The rate of positive animals increased gradually at each sampling, showing a positive correlation between the ani- mal age and the total number of positives $(\mathrm{r}=0.18 ; \mathrm{P}<0.05)$. In the present study, nematodes were detected only in animals over 16 months of age, indicating that puberty promotes an increased susceptibility to infestation. The results of the present study corroborate the findings of Facuri Filho et al. (1990) and Leite et al. (1993) regarding the higher frequency of parasites in older animals; however, the results contradict those of Martins Jr. et al. (1971), who found rates of $100 \%$ positivity in adults and calves of up to one month of age from a Gir herd and 85\% in calves between one and six months old.

Regarding the frequency of parasitism by Raillietia spp., a negative correlation was observed when measuring the total number of infested animals relative to the dates of each of the five samplings of the experiment $(r=-0.22$, $\mathrm{IC}=-0.32$ to $-0.11 ; \mathrm{P}<0.05)$. However, the same analysis of the results observed in all three groups was positive $(\mathrm{r}=$ 0.27 , IC $=0.16$ to $0.37 ; \mathrm{P}<0.05$ ). Therefore, the group of older animals (GC) always had more infested animals than the younger groups. Those data corroborate the findings of Leite et al. (1989) and Araujo Filho et al. (1996), who also used ear washing as a diagnostic method and found that raillietiosis was more common in the adults, although it could be present in the calves. The discrepancy between the results obtained when analyzing by group and by sampling may be attributed to the diagnostic method used in this study, which, when performed every three months in the same ear, may have decreased both the infection rate and the parasitic burden. According to Leite et al. (1989), the method of EAC washing is efficient at removing mites and may be used as an adjuvant treatment for bovine raillietiosis. However, despite the decreased number of parasites, some specimens were also found in the subsequent samples, which is possibly due to a re-infestation. The differences may also be due to the method in this study of using an automatic syringe with a volume smaller than the $100 \mathrm{ml}$ recommended by Leite et al. (1989), which may have allowed a low-level infestation to remain in the EAC and a subsequent propagation of the parasite population.

The highest percentage of animals infested by Raillietia spp., was $42.2 \%$ of the total, observed in the first sampling (S1). Leite et al. (1989) obtained exactly the same percentage of carriers, which was similar to the values observed by Araujo Filho et al. (1996) (45.2\%). In contrast, Nunes \& Nunes (1975), Nunes et al. (1980) and Rebouças \& Fujii (1999) obtained higher values of $100 \%, 85.0 \%$ and $77.5 \%$, respectively.

Nunes et al. (1975) collected up to 161 mites per host, which is more than the numbers obtained in the present study, but the parasite sampling was performed during an autopsy. Rebouças \& Fujii (1999), who also used ear washing, reported parasitic rates higher than those obtained in the present study. The above studies did not specify the age of the animals examined, which is a factor that could explain the high infestation rate that was found. As for the average load of parasites in the present study, it was found that the values were lower in the calves (GA and GB) than in the heifers (GC) in all samples. This finding is similar to 
the data from Leite et al. (1989), who obtained 1.8 and 3.3 mites per calf and heifer, respectively.

In the present study, only the individuals over 16 months of age showed behavioral changes that could be attributed to moderate otitis, such as distress and sporadic ear movements (Table 2). A specific clinical examination confirmed that these individuals had an evident yellowish fluid ear secretion that could cover up to the entire first third of the pinna, which is typical of Rhabditis. The epidermis was reddish with small ulcerated areas, and the regional lymph nodes were slightly enlarged. The absence of neurological symptoms due to parasitic otitis in the animal age groups studied (4 to 45 months of age) agrees with the studies of Verocai et al. (2007) and Campos et al. (2009), who found facial nerve involvement only in adult cattle older than four years. According to reports by Martins Jr (1974), only older bovines showed clinical signs of otitis, which was associated with a massive infestation by nematodes, while the calves, though infected, were asymptomatic. Duarte et al. (2001) assessed 278 animals of the Gir breed and found a $60.1 \%$ rate of infestation with clinical signs and $20 \%$ rate of subclinical cases. Msolla et al. (1993) reported that the subjects affected by Rhabditis may present with apathy or remain asymptomatic for long periods.

There were no clinical changes resulting from otitis in the cattle infested by only mites, corroborating Nunes \& Nunes (1975), who reported the animals appeared healthy, despite the $100 \%$ infestation and high parasitic rates found. Although asymptomatic cases are the most common, there are reports that a progression to more severe cases is not uncommon, including edema at the base of the ear, anorexia, purulent discharge, occlusion of the external auditory canal, hearing loss and perforation of the tympanum with involvement of the inner ear structures and the Central Nervous System, leading to death (Faccini et al. 1992).

The simultaneous occurrence of the two parasites in the same host was found in the present study at a rate of $6.3 \%$. Similar findings were also reported by Nunes et al. (1980) and Leite et al. (1989), who found lower rates than those described here.

It is believed that the mite Rallietia spp. only feeds on the cerumen and cell debris; however, its presence may result in areas of erosion in addition to an intense irritation of the EAC with inflammatory lesions, such as edema, a local temperature increase and secretions (Nunes et al. 1980, Ferry et al. 2011), which favor the survival and multiplication of the nematode Rhabditis.

We were unable to demonstrate a correlation between a nematode infestation ear and climatic factors. Previous studies performed in Brazil indicated no influence by the climate on the increase or exacerbation of the clinical cases of parasitic otitis caused by Rhabditis ssp. (Vieira 1998; Duarte et al. 2001b). However, Jibbo (1966) and Obatolu et al. (1999) found a positive correlation between the growth in parasitosis cases and humid and warm months in Africa that may be due to increases in fly populations, which have been identified as nematode vectors to the hosts.

The parasitism caused by the mite Raillietia spp. did not show a significant correlation with the climate parameters.
Similar results were obtained by Araújo et al. (1996), who compared this variable in two regions of São Paulo that have different average temperatures.

The small variation of relative humidity and temperature, which remained high during the twelve months of this present study, could explain the results obtained and support the hypothesis that in the region where the study was performed, the transmission of the etiological agents of parasitic otitis in cattle occurs throughout the year. Those findings differ substantially from those reported by Jibbo (1966) and Obatolu et al. (1999) in Africa, probably influenced by climatic variations resulting from the local altitudes.

\section{CONCLUSIONS}

The study results allow us to conclude that the implementation of control measures of the parasitic otitis in Gir cattle should consider the biology and dynamics of both auricular parasites.

Therapeutic protocols should be implemented early, with special attention to asymptomatic animals to avoid chronic disease.

Acknowledgements.- To Federal University of Minas Gerais (Pró Reitoria de Pesquisa), FAPEMIG (Fundação de Amparo à Pesquisa do Estado de Minas Gerais), CAPES (Coordenação de Aperfeiçoamento de Pessoal de Nível Superior), and CNPq (Conselho Nacional de Desenvolvimento Científico e Tecnológico) for financial support.

\section{REFERENCES}

Abdalla M.S., Peixoto T.C., Alves P.A.M., França T.N. \& Brito M.F. 2008. Aspectos anatomopatológicos da otite causada por Rhabditis sp. em bovinos no estado do Rio de Janeiro. Brazil. Available at <http://www.sovergs. com.br/conbravet2008/anais/cd/resumos/R0743-1.pdf> Accessed on February 3, 2009.

Araujo Filho R.S., Vianna S.S.S. \& Pereira J.R. 1996. Aspectos epidemiológicos de Raillietia auris (Leidy, 1872) Trouessart, 1902 (Mesostigmata: Raillietidae), no Vale do Paraíba e Região Serrana, Estado de São Paulo, Brasil. Revta Bras. Parasitol. Vet. 5(1):33-38.

Ayres M., Ayres Jr M. \& Santos A.S. 2003. Bioestat 3.0: Aplicações Estatísticas nas Áreas das Ciências Biológicas e Médicas. Soc. Civil Mamirauá, Belém. 291p.

Brum K.B. \& Lemos R.A.A. 2007. Otite parasitária, p.575-578. In: Riet-Correa F., Schild A.L., Lemos R.A.A. \& Borges J.R.J. (Eds), Doenças de Ruminantes e Equinos. $3^{\text {a }}$ ed. Palloti, Santa Maria, RS.

Campos S.B.S., Serodio J.J. \& Brazil D.S. 2009. Evolução clínica, diagnóstico, tratamento e achados de necropsia da otite parasítica por Rhabditis sp. em touro da raça Gir: relato de caso. Available at <http://www.revistas. ufg.br/index.php/vet/article/viewArticle/7883/5718> Accessed on December 21, 2009.

Duarte E.R., Melo M.M. \& Hamdan J.S. 2001. Epidemiological aspects of bovine parasitic otitis caused by Rhabditis spp. and/or Raillietia spp. in the State of Minas Gerais, Brazil. Vet. Parasitol. 101(1):45-52.

Duarte E.R. \& Hamdan J.S. 2004. Otitis in cattle: an aetiological review. J. Vet. Med. B 51:1-7.

Faccini J.L.H., Fonseca A.H., Costa A.L. \& Leite R.C. 1992. Distribuição geográfica e prevalência das espécies do gênero Raillieitia Trouessart em bovinos no Brasil. Revta Bras. Parasitol. Vet. 1(2):109-110.

Facuri Filho E.J., Guimarães A.M., Oliveira P.R. \& Garcia A.M. 1990. Ocorrência de otite parasitária em um rebanho da raça Gir, no município de Betim, Minas Gerais. Anais 4ํㅡㄹ Congresso Mineiro de Medicina Veterinária, Belo Horizonte, Brasil. Escola de Veterinária da UFMG, Belo Horizonte, p.95. 
Ferry F.R.A., Faccini J.L.H. \& Inada T. 2011. The role of ear mites of the genus Raillietia (Acari: Raillietiidae) in otitis of domestic ruminants. Pesq. Vet. Bras. 31(11):981-984.

Heffner R.S. \& Heffner H.E. 1983. Effect of cattle ear mite infestation on hearing in a cow. J. Am. Vet. Med. Assoc. 182(6):612-614.

IESFATO 2009. Instituto de Educação Superior São Francisco de Assis, Teófilo Otoni, MG. Available at <http://www.iesfato.com.br/iesfato/instituto/teofilootoni.asp> Accessed on December 10, 2009.

Jibbo J.M.C. 1966. Bovine parasitic otitis. Bull. Epizoot. Dis. Afr. 14:59-63.

Jubb T.F., Vassalo R.L. \& Wroth R.H. 1993. Suppurative otitis in cattle associated with ear mites Raillietia auris. Aust. Vet. J. 70(9):354-355.

Ledic I.L. 2009. 0 Gir leiteiro "puro": uma realidade na América Latina. Available at <http://girbrasilartigos.blogspot.com/2010/01/o-gir-leiteiro-puro-uma-realidade-na.html> Accessed on November 10, 2009.

Leite R.C., Faccini J.L.H. \& Costa A.L. 1989. Avaliação de uma técnica in vivo para medir a infestação por ácaros do gênero Raillietia Trouessart (Acari) em bovinos [Evaluation of an in vivo technique to measure the infestation by mites of the genus Raillietia Trouessart (Acari) in cattle]. Mem. Inst. Oswaldo Cruz 84(Supl.4):309-311.

Leite R.C., Nunes V.A., Nunes I.J., Costa A.L., Faccini J.L.H. \& Lopes C.W.G. 1993. Otite parasitária bovina por nematóides rhabditiformes: Aspectos epidemiológicos e clínicos. Revta Bras. Med. Vet. 15(2):49-51.

Leite R.C., Leite R.C. \& Faccini J.L.H. 1994. The diagnosis and treatment of bovine parasitic otitis caused by rhabditiform nematodes. Rev. Bras. Parasitol. Vet. 3(1):69-70.

Martins Jr W. 1974. Nematóides (Rhabditida, Chitwood, 1933 - Rhabditidae e Cephalobidae) envolvidos em otite de bovinos no Brasil. Dissertação de Mestrado, Escola de Veterinária da UFMG, Belo Horizonte, MG. $66 \mathrm{p}$.
Msolla P., Semuguruka W.D., Kasuku A.A. \& Shoo M.K. 1993. Clinical observations on bovine parasitic otitis in Tanzania. Trop. Anim. Hlth. Prod. 25(1):15-18.

Nunes V.A. \& Nunes I.J. 1975. Técnica de exame "post-mortem" do sistema auditivo, aplicada ao estudo de otites em bovino. Arq. Esc. Vet. UFMG 27(2):155-61.

Nunes V.A., Nunes I.J., Santos M.N., Chquiloff M.A.G. \& Silva J.M.L. 1980. Patologia da infecção do ouvido de bovinos por Raillietia auris (Leidy, 1872) Trouessart, 1902 (Acari - Mesostigmata): aspectos macroscópicos. Arq. Esc. Vet. UFMG 32(3):229-234.

Obatolu U.U., Pfukenyi D.M. \& Ushe T. 1999. A retrospective epidemiological study of parasitic otitis in cattle in the South-East Lowveld of Zimbabwe. Zimbabwe Vet. J. 30(1):19-24.

Rebouças M.M. \& Fujii T.U. 1999. Raillietia auris (Acarimeostigmata): dinâmica do parasitismo na espécie bovina, na região do Vale do Ribeira, São Paulo, Brasil. Arqs Inst. Biológico, São Paulo, 66(1):139-141.

Rentero N. 2008. Leite puxa as vendas de sêmen. Available at <http://www. asbia.org.br/?empresa/noticias_ler,53> Accessed on March 6, 2008.

Sampaio I.B.M. 2007. Estatística aplicada à experimentação animal. $3^{a}$ ed. Fundação de Ensino e Pesquisa em Medicina Veterinária e Zootecnia, Belo Horizonte. 211p.

Verocai G.G., Fernandes J.I., Correia T.R., Melo R.M.P.S., Alves P.A.M. \& Scott F.B. 2007. Otite parasitária bovina por nematóides rhabditiformes em vacas Gir no estado do Rio de Janeiro, Brasil. Revta Bras. Parasitol. Vet. 16(2):105-107.

Vieira M.C.M., Silva L.A.F., Borges N.C., Araujo J.L.B., Santin A.P.I. \& Silva E.V. 1998. Estudo da prevalência de otites clínicas por Rhabditis sp. em bovinos da raça Gir no estado de Goiás. Anais Esc. Agron. Vet., Goiânia, 28(2):19-29. 